GRASAS Y ACEITES 72 (4)

October-December 2021, e437

ISSN-L: 0017-3495

https://doi.org/10.3989/gya.1004202

\title{
A novel bleaching approach: Microwave assisted sunflower oil bleaching and optimization
}

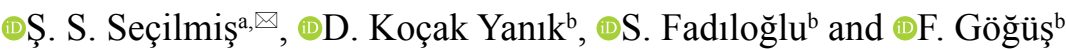 \\ ${ }^{a}$ Department of Food Processing, Vocational School of Technical Sciences of Gaziantep University, Üniversite Bulvarı 27310 Gaziantep, Turkey \\ ${ }^{b}$ Department of Food Engineering, Engineering Faculty of Gaziantep University, Üniversite Bulvar1 27310 Gaziantep, Turkey \\ ${ }^{\otimes}$ Corresponding author: selcuksecilmis@gantep.edu.tr
}

Submitted: 29 September 2020; Accepted: 24 November 2020; Published online: 12 January 2022

\begin{abstract}
SUMMARY: The factors affecting the microwave bleaching of sunflower oil and the interaction between them were investigated and optimized by response surface methodology using a three-factor five-level central composite rotatable design. Microwave power, time and the amount of bleaching clay were selected as independent variables studied in the range of 70-120 W, 2-15 min, and 0.01-0.5\%. The dependent variables that measure the bleaching efficiency and oil quality were evaluated as hue angle, chroma and totox value. Optimization was carried out by minimizing totox and chroma and maximizing hue angle. Hue angle, chroma and totox were found as $96.91,37.66$ and 23.31 under optimal conditions. Optimal microwave bleaching was successfully performed by using less bleaching clay $(0.4 \%)$ and a shorter time ( $8 \mathrm{~min}$ ) compared to the current industrial application without any adverse effect on oil quality. Hence, microwave bleaching is thought to be an alternative method for the bleaching of edible oils.
\end{abstract}

KEYWORDS: Bleaching; Bleaching efficiency; Microwave; Optimization; Sunflower seed oil

RESUMEN: Un enfoque novedoso de blanqueamiento: optimización del proceso asistido por microondas de aceite de girasol. Los factores que afectan al blanqueamiento asistido por microondas del aceite de girasol y la interacción entre ellos se investigaron y optimizaron mediante la metodología de superficie de respuesta utilizando un diseño central giratorio compuesto de tres factores y cinco niveles. La potencia del microondas, el tiempo y la cantidad de arcilla blanqueadora se seleccionaron como variables independientes estudiadas en el rango de 70-120 W, 2-15 min y 0,01-0,5\%. Las variables dependientes que miden la eficiencia del blanqueamiento y la calidad del aceite se han evaluado como ángulo de tono, croma y valor totox. La optimización se llevó a cabo minimizando el totox y el croma y maximizando el ángulo de tono. El ángulo de tono, el croma y el totox se encontraron en 96,91, 37,66 y 23,31 en condiciones óptimas. El blanqueamiento por microondas óptimo se ha realizado con éxito utilizando arcilla blanqueadora más baja ( $0,4 \%)$ y un tiempo más corto (8 min). En comparación con la aplicación industrial actual sin ningún efecto adverso sobre la calidad del aceite. Por tanto, se cree que el blanqueamiento asistido por microondas es un método alternativo para blanquear los aceites comestibles.

PALABRAS CLAVE: Aceite de semilla de girasol; Blanqueamiento; Eficacia de blanqueo; Mejoras; Microondas

Citation / Cómo citar este artículo: Seçilmiș SS, Koçak Yanık D, Fadıloğlu S, Göğüs F. 2021. A novel bleaching approach: Microwave assisted sunflower oil bleaching and optimization. Grasas Aceites 72 (4), e437. https://doi.org/10.3989/gya.1004202

Copyright: (C2021 CSIC. This is an open-access article distributed under the terms of the Creative Commons Attribution 4.0 International (CC BY 4.0) License. 


\section{INTRODUCTION}

Bleaching is the most important step in the edible oil refining process and can be described as a process which is based on removing undesirable color pigments and other undesirable impurities from the neutralized oil by using a certain amount of bleaching earth or active carbon under the determined conditions. Generally, the bleaching process is carried out at temperatures between $90-120^{\circ} \mathrm{C}$, using clay $0.5-2.0 \%$, in times from 20-30 minutes (Zschau, 2001). The quality of the bleached oil depends on the type of earth, dosage, bleaching time, mixing, bleaching temperature and pressure. The surface area of the earth is a critical feature in the bleaching process. Clays are activated by mineral acids in order to obtain better bleaching quality with increasing specific surface area. Clay with $40-60 \mathrm{~m}^{2} / \mathrm{g}$ dry clay surface area originally, can be increased up to $200 \mathrm{~m}^{2} / \mathrm{g}$ dry clay (Hymore, 1996). The bleaching process in today's edible oil industry is applied batch-wise with long process times and high temperatures by using large amounts of clay. The clay absorbs approximately $0.36 \mathrm{~kg}$ of oil/ $/ 1 \mathrm{~kg}$ of clay (Gupta, 2017). In the existing conventional method, the desired oil color quality is achieved by increasing the amount of clay, which leads to increasing oil losses and environmental problems. Therefore, the development of new bleaching methods to overcome the problems involved in the process is necessary for the vegetable oil industry.

The use of microwave has become very popular in various industrial applications over recent years. Microwave is used especially in the food industry to reduce process time and increase food quality. In the literature, microwave heating is described as a continued promising method among the other electric heating technologies such as radio frequency, ohmic, and infrared (Torrealba-Meléndez et al., 2015; Zhang et al., 2006). Specific heat is a very important factor in microwave heating (Meda et al., 2017). In particular, materials with low specific heat can be heated rapidly when subjected to microwave. Vegetable oils have a lower specific heat than water so they may be heated by microwave faster than water of the same weight (Schiffmann, 2014). Microwave is preferred for the heating of edible oils because of the reduction in heating time, providing inner penetration and faster heating (Gjorgjevich et al., 2012). Microwave also plays an important role in the sorption capacity of clays. Li et al., 2007 showed that the sorption of cetylpyridinium chloride into bentonite was greatly influenced by microwave. The velocity constant of the sorption reaction was increased 107.6 times, and the free energy of the sorption reaction system was decreased.

There are vast numbers of studies on improving the bleaching process of oils. In all these studies, the type and amount of bleaching agent, mixing time, temperature and pressure are the parameters examined (Skevin et al., 2012; Salawudeen et al., 2014; Chew et al., 2017; Mustafa and
Abusabah, 2019; Boroujeni et al., 2020.) by keeping the conventional heating method as the same. In only a few studies, new technologies such as ultrasound and high voltage electric field were used as alternative techniques to the conventional heating process (Su et al., 2013; Abedi et al., 2016; İçyer and Durak, 2018). Although there are a few studies (Boukerroui and Quali, 2002; Foletto et al., 2013) in which the Brazilian bentonite activated by microwave treatment has been used in the bleaching of soybean oil in the literature, this current study is the first one in which the bleaching process has been applied directly with microwave treatment.

Therefore, the main purpose of this study was to evaluate the effect of microwave technology on the bleaching efficiency of sunflower seed oil and to optimize different parameters in the bleaching process, such as amount of bleaching earth, microwave power and process time, based on total oxidation value and color reduction in bleached sunflower oil.

\section{MATERIAL AND METHODS}

\subsection{Materials and chemicals}

The non-bleached sunflower oils used in this study were obtained from a local refinery. Sunflower oil samples were placed in dark bottles and stored at $-18{ }^{\circ} \mathrm{C}$ until bleaching. Acid-activated (Suprefast M1FF) bleaching clay was also procured from same refinery (Gaziantep, Turkey). All chemicals and reagents used in this study were analytical grade and purchased from Sigma-Aldrich.

\subsection{Experimental design}

A three-level, five factorial central composite rotatable design (CCRD) was employed to analyze the effects of microwave assisted factors on the bleaching and to optimize the bleaching conditions to obtain maximum bleaching quality. The independent variables were selected as microwave power (A), amount of clay (B) and bleaching time (C). The levels of the independent variables were defined as between A, $70-120 \mathrm{~W} ; \mathrm{B}, 0.01-0.5 \%$ (w/w); C, 2-10 min. Preliminary experiments were carried out to obtain information about the independent variables and their levels prior to the experimental design. The employed CCRD was composed of 20 experiments consisting of 6 center points. At the end of optimization, verification of experiments was carried out under the optimal conditions and the average value for the experiments was compared to the predicted value.

\subsection{Microwave-assisted bleaching}

Microwave-assisted bleaching (MWB) treatments were performed using a microwave reactor (CEM, Discover SP). Bleaching was carried out in a $35-\mathrm{ml}$ glass vessel. The vessel was not fully filled to avoid oil splash. $20 \mathrm{~g}$ sunflower oil were weighed into the vessels in all experiments. The 
bleaching earth was weighed for each vessel according to the amounts determined in the experimental design. After the addition of clay, the tube was sealed with a rubber lid (CEM) and placed in the microwave reactor. In all experiments, stirring speed mode was set on high. The mixing of clay and sunflower oil was carried out only in the reactor and during the bleaching period. The levels of microwave power and time were adjusted according to the experimental design. This microwave system consisted of an infrared sensor for temperature measurement. Therefore, temperature values varied depending on the microwave power reported during the experiment. At the end of the microwave treatment, the mixture of sunflower oil and clay was centrifuged (EBA 20, Hettich) at $6.000 \mathrm{rpm}$ at $25^{\circ} \mathrm{C}$ for $10 \mathrm{~min}$. Sunflower oil was separated easily from the clay because of the clay sticking to the wall of the tube. The sunflower oils bleached by this way were stored in dark amber sample bottles at $-18^{\circ} \mathrm{C}$ until further analysis.

\subsection{Determination of oxidation parameters}

Peroxide value (PV) was determined according to AOCS standard method Cd 8-53 (AOCS, 1998). The p-anisidine value $(\mathrm{AV})$ in sunflower oil was determined by the spectrophotometric (Optima, SP-3000nano, Japan) method as described in the AOCS Official Method Cd
18-90 (AOCS, 1998). PV and AV were converted to total oxidation value (Totox) according to Equation 1.

$$
\text { Totox value }=2 \mathrm{PV}+\mathrm{AV}
$$

\subsection{Color measurement}

The color of the samples was determined by a HunterLab Colorflex colorimeter with standard illumination $\mathrm{D}_{65}$, and colorimetric normal observer angle of $10^{\circ}$. Color values were evaluated as $\mathrm{L}^{*}, \mathrm{a}^{*}$ and $\mathrm{b}^{*}$. Measured values $\mathrm{L}^{*}, \mathrm{a}^{*}$ and $\mathrm{b}^{*}$ were also converted to chroma and hue angle values given below in Equations 2 and 3, respectively.

$$
\begin{aligned}
& \text { Chroma }=\sqrt{(a *) 2+(b *) 2} \\
& \text { Hue angle }=\tan ^{-1}\left(\mathrm{~b}^{*} / \mathrm{a}^{*}\right)
\end{aligned}
$$

\subsection{Statistical analysis}

The experimental design and statistical analysis were conducted using Design Expert version 7.0 software (StateEase Inc., Minneapolis, Minn., U.S.A.). Statistical parame-

\begin{tabular}{|c|c|c|c|c|c|c|c|c|c|}
\hline \multirow{3}{*}{ Runs } & \multicolumn{3}{|c|}{ FACTORS } & \multicolumn{6}{|c|}{ RESPONSES } \\
\hline & \multirow{2}{*}{$\begin{array}{c}\mathbf{A} \\
\text { (Watt) }\end{array}$} & \multirow{2}{*}{ B (\%) } & \multirow{2}{*}{$\mathrm{C}(\mathrm{s})$} & \multicolumn{2}{|c|}{ Totox } & \multicolumn{2}{|c|}{ Hue Angle } & \multicolumn{2}{|c|}{ Chroma } \\
\hline & & & & Experimental & Predicted & Experimental & Predicted & Experimental & Predicted \\
\hline 1 & 95 & 0.26 & 360 & $22.02 \pm 0.61$ & 22.36 & $96.24 \pm 0.05$ & 96.73 & $41.21 \pm 0.03$ & 39.80 \\
\hline 2 & 110 & 0.11 & 241 & $20.50 \pm 0.06$ & 19.49 & $93.55 \pm 0.02$ & 93.41 & $48.02 \pm 0.01$ & 49.86 \\
\hline 3 & 120 & 0.26 & 360 & $22.73 \pm 0.08$ & 23.82 & $96.99 \pm 0.01$ & 97.30 & $39.70 \pm 0.01$ & 37.37 \\
\hline 4 & 95 & 0.26 & 120 & $19.27 \pm 0.01$ & 19.72 & $92.78 \pm 0.02$ & 92.90 & $50.19 \pm 0.01$ & 49.07 \\
\hline 5 & 80 & 0.11 & 241 & $19.28 \pm 0.01$ & 19.76 & $93.56 \pm 0.01$ & 93.52 & $50.05 \pm 0.01$ & 50.41 \\
\hline 6 & 110 & 0.40 & 503 & $29.91 \pm 0.90$ & 28.69 & $99.43 \pm 0.01$ & 99.47 & $30.57 \pm 0.02$ & 30.41 \\
\hline 7 & 95 & 0.50 & 360 & $21.73 \pm 0.24$ & 22.43 & $97.48 \pm 0.01$ & 97.40 & $37.47 \pm 0.01$ & 38.67 \\
\hline 8 & 95 & 0.26 & 360 & $23.14 \pm 0.73$ & 22.36 & $96.84 \pm 0.02$ & 96.73 & $38.97 \pm 0.01$ & 39.80 \\
\hline 9 & 95 & 0.26 & 360 & $22.85 \pm 0.73$ & 22.36 & $96.73 \pm 0.01$ & 96.73 & $39.40 \pm 0.01$ & 39.80 \\
\hline 10 & 110 & 0.40 & 241 & $21.26 \pm 0.01$ & 21.12 & $96.36 \pm 0.01$ & 96.08 & $40.34 \pm 0.05$ & 41.72 \\
\hline 11 & 95 & 0.26 & 360 & $21.69 \pm 1.14$ & 22.36 & $96.63 \pm 0.02$ & 96.73 & $40.44 \pm 0.04$ & 39.80 \\
\hline 12 & 80 & 0.40 & 503 & $23.31 \pm 0.14$ & 23.59 & $97.31 \pm 0.01$ & 97.44 & $37.18 \pm 0.04$ & 35.60 \\
\hline 13 & 110 & 0.11 & 503 & $26.17 \pm 0.01$ & 26.12 & $96.06 \pm 0.01$ & 95.86 & $42.75 \pm 0.01$ & 44.12 \\
\hline 14 & 95 & 0.01 & 360 & $20.55 \pm 0.02$ & 20.90 & $93.67 \pm 0.01$ & 93.76 & $55.48 \pm 0.01$ & 53.92 \\
\hline 15 & 95 & 0.26 & 360 & $22.98 \pm 0.03$ & 22.36 & $97.10 \pm 0.01$ & 96.73 & $38.67 \pm 0.01$ & 39.80 \\
\hline 16 & 95 & 0.26 & 600 & $28.58 \pm 0.02$ & 29.16 & $97.76 \pm 0.01$ & 97.65 & $34.80 \pm 0.01$ & 35.55 \\
\hline 17 & 70 & 0.26 & 360 & $19.84 \pm 0.01$ & 19.80 & $96.00 \pm 0.01$ & 95.70 & $40.15 \pm 0.01$ & 42.12 \\
\hline 18 & 95 & 0.26 & 360 & $21.65 \pm 0.74$ & 22.36 & $96.86 \pm 0.01$ & 96.73 & $40.05 \pm 0.04$ & 39.80 \\
\hline 19 & 80 & 0.40 & 241 & $19.70 \pm 0.07$ & 19.01 & $94.05 \pm 0.02$ & 94.24 & $47.06 \pm 0.02$ & 45.94 \\
\hline 20 & 80 & 0.11 & 503 & $24.01 \pm 1.21$ & 23.41 & $95.56 \pm 0.01$ & 95.78 & $46.34 \pm 0.01$ & 45.60 \\
\hline
\end{tabular}
ters such as lack of fit, the coefficient of determination $\left(\mathrm{R}^{2}\right)$

TABLE 1. Experimental and estimated values obtained for responses

A: Microwave power (W), B: Earth amount (\%), C: Time (Sec). \pm : Standard Deviation. Data are means of triplicates 
and the F-test value obtained from the analysis of variance (ANOVA) were used to evaluate the best fitting polynomial model. Regression analysis and three-dimensional surface plots were generated to understand the effect of microwave-assisted conditions on response variables. All experiments were performed in three replicates and the results were given as mean \pm standard deviation.

\section{RESULTS AND DISCUSSION}

\subsection{Fitting the model}

The experimental design and the experimental results for the microwave bleaching of sunflower oil are present- ed in Table 1 . The bleaching efficiency and the oil quality have been analyzed in terms hue angle, chroma and totox value for MWB sunflower oil. The totox value the MWB sunflower oil obtained in this study ranged from 19.27 to 29.91; while the hue angle and chroma ranged from 92.78 to 99.43 and 30.57 to 55.48 , respectively.

The multiple regressions and backward elimination were employed to get the best fitting statistical model for each response. Table 2 summarizes the results from the ANOVA and regression analyses for the hue angle, chroma and totox values. Non-significant lack of fit and high $\mathrm{R}^{2}$ value indicate that the statistical model fits well with data (Içyer and Durak, 2018; Islam et al., 2018). The quadratic model was deter-

TABLE 2. ANOVA results for responses

\begin{tabular}{|c|c|c|c|c|c|}
\hline Source & Sum of squares & Df & Mean Square & F value & p-value \\
\hline Model (Totox) & 146.07 & 6 & 24.35 & 31.60 & $<0.0001$ \\
\hline A-MW power & 19.73 & 1 & 19.73 & 25.61 & 0.0002 \\
\hline B-Clay content & 2.82 & 1 & 2.82 & 3.65 & 0.0782 \\
\hline C-Time & 107.44 & 1 & 107.44 & 139.45 & $<0.0001$ \\
\hline $\mathrm{AB}$ & 2.84 & 1 & 2.84 & 3.69 & 0.0770 \\
\hline $\mathrm{AC}$ & 4.45 & 1 & 4.45 & 5.77 & 0.0319 \\
\hline $\mathrm{C}^{2}$ & 8.79 & 1 & 8.79 & 11.41 & 0.0049 \\
\hline Residual & 10.02 & 13 & 0.77 & & \\
\hline Lack of fit & 7.72 & 8 & 0.96 & 2.10 & 0.2154 \\
\hline Pure error & 2.30 & 5 & 0.46 & 31.60 & $<0.0001$ \\
\hline Core total & 156.09 & 19 & - & 25.61 & 0.0002 \\
\hline \multicolumn{6}{|c|}{$\mathrm{R}^{2}=0.94$, Adj. $\mathrm{R}^{2}=0.91$, Pred. $\mathrm{R}^{2}=0.83$, Adeq Precision $=18.37$} \\
\hline Model (Hue Angle) & 54.30 & 7 & 7.76 & 95.13 & $<0.0001$ \\
\hline A-MW power & 3.11 & 1 & 3.11 & 38.17 & $<0.0001$ \\
\hline B-Clay amount & 15.99 & 1 & 15.99 & 196.12 & $<0.0001$ \\
\hline C-Time & 27.24 & 1 & 27.24 & 334.08 & $<0.0001$ \\
\hline $\mathrm{AB}$ & 1.90 & 1 & 1.90 & 23.32 & 0.0004 \\
\hline $\mathrm{BC}$ & 0.44 & 1 & 0.44 & 5.45 & 0.0378 \\
\hline $\mathrm{B}^{2}$ & 2.33 & 1 & 2.33 & 28.57 & 0.0002 \\
\hline $\mathrm{C}^{2}$ & 3.77 & 1 & 3.77 & 46.19 & $<0.0001$ \\
\hline Residual & 0.98 & 12 & 0.08 & & \\
\hline Lack of fit & 0.56 & 7 & 0.08 & 0.97 & 0.5329 \\
\hline Pure error & 0.42 & 5 & 0.08 & 95.13 & $<0.0001$ \\
\hline Core total & 55.27 & 19 & - & 38.17 & $<0.0001$ \\
\hline \multicolumn{6}{|c|}{$\mathrm{R}^{2}=0.98$, Adj. $\mathrm{R}^{2}=0.97$, Pred. $\mathrm{R}^{2}=0.95$. Adeq Precision $=36.56$} \\
\hline Model (Chroma) & 627.77 & 6 & 104.63 & 36.32 & $<0.0001$ \\
\hline A-MW power & 27.47 & 1 & 27.47 & 9.54 & 0.0086 \\
\hline B-Clay amount & 280.68 & 1 & 280.68 & 97.44 & $<0.0001$ \\
\hline C-Time & 220.64 & 1 & 220.64 & 76.59 & $<0.0001$ \\
\hline $\mathrm{BC}$ & 15.25 & 1 & 15.25 & 5.29 & 0.0386 \\
\hline $\mathrm{B}^{2}$ & 76.89 & 1 & 76.89 & 26.69 & 0.0002 \\
\hline $\mathrm{C}^{2}$ & 11.54 & 1 & 11.54 & 4.01 & 0.0667 \\
\hline Residual & 37.45 & 13 & 2.88 & & \\
\hline Lack of fit & 32.85 & 8 & 4.11 & 4.47 & 0.0580 \\
\hline Pure error & 4.59 & 5 & 0.92 & 36.32 & $<0.0001$ \\
\hline Core total & 665.22 & 19 & & 9.54 & 0.0086 \\
\hline $\mathrm{R}^{2}=0.94$, Adj. $\mathrm{R}^{2}=0.9$ & , Adeq Precision $=$ & & & & \\
\hline
\end{tabular}


mined as the best fitting model according to non-significant lack of fit and $\mathrm{R}^{2}$ values for all responses (Table 2). Adequate precisions for totox, hue angle and chroma were found as $18.37,36.56$ and 22.02 . These values were higher than 4. Therefore, it can be said that there is a good correlation between the estimated values and experimental data (Gasemloo et al., 2019). Similarly, Chew et al. (2017) and Garcia-Moreno et al. (2013) reported that the quadratic model was found suitable for the bleaching studies based on totox and color parameters. The reduced model created with the terms that are only statistically significant are expressed in Equations (4), (5), (6) for totox (Y1), hue angle (Y2) and chroma values (Y3), respectively:

$$
\begin{gathered}
Y 1=22.03+1.20 x \mathrm{~A}+0.45 x \mathrm{~B}+2.80 x C \\
+0.59 x A x B+0.74 x A x C+0.77 x C 2 \\
Y 2=99.67+0.47 x A+1.08 x B+1.41 x C \\
+0.48 x A x B+0.24 x B x C-0.4 x B 2-0.51 x C 2 \\
Y 3=39.78-1.41 x A-4.43 x B-4.02 x C \\
-1.38 x B x C+2.30 x B 2+0.89 x C 2
\end{gathered}
$$

The magnitude of coefficients for bleaching time and amount of clay are higher than the coefficients for current microwave power and other interactions. On the other hand, the magnitude of coefficients for microwave power and amount of clay are higher than the coefficients for current hue angle, chroma and other interactions, indicating that these parameters have a more significant effect on hue angle, chroma and totox values. The other parameters seem to have a quadratic effect on the hue angle, chroma and totox values.

\subsection{Effect of microwave-assisted bleaching parameters on the oxidation of oil}

The oxidation of fats and oils during bleaching is one of the important deteriorative reactions. Totox value is one of the important ways to express the total oxidation degree of fats and oils. Hence the totox value was taken as oxidation indicator in this study. Among the independent variables, microwave power, time and their interaction (AC) were found to significantly affect $(\mathrm{p}<0.05)$ the Totox value. The second-order term of time (C2) also had significant ( $\mathrm{p}<$ 0.05 ) effects on the totox value. On the other hand, neither the first-order term of amount of bleaching clay nor its interactions with other responses $(\mathrm{AB}, \mathrm{BC})$ had a significant $(p>0.05)$ effect on the totox value of bleached sunflower oil. The 3D response surface plots for the totox value of bleached sunflower oil samples as a function of independent variables are shown in Figure 1a. The totox value for sunflower oil increased with the rise in microwave power and longer irradiation time. The exposure of material to high microwave power increased the temperature of the material. Therefore, the increase in temperature due to
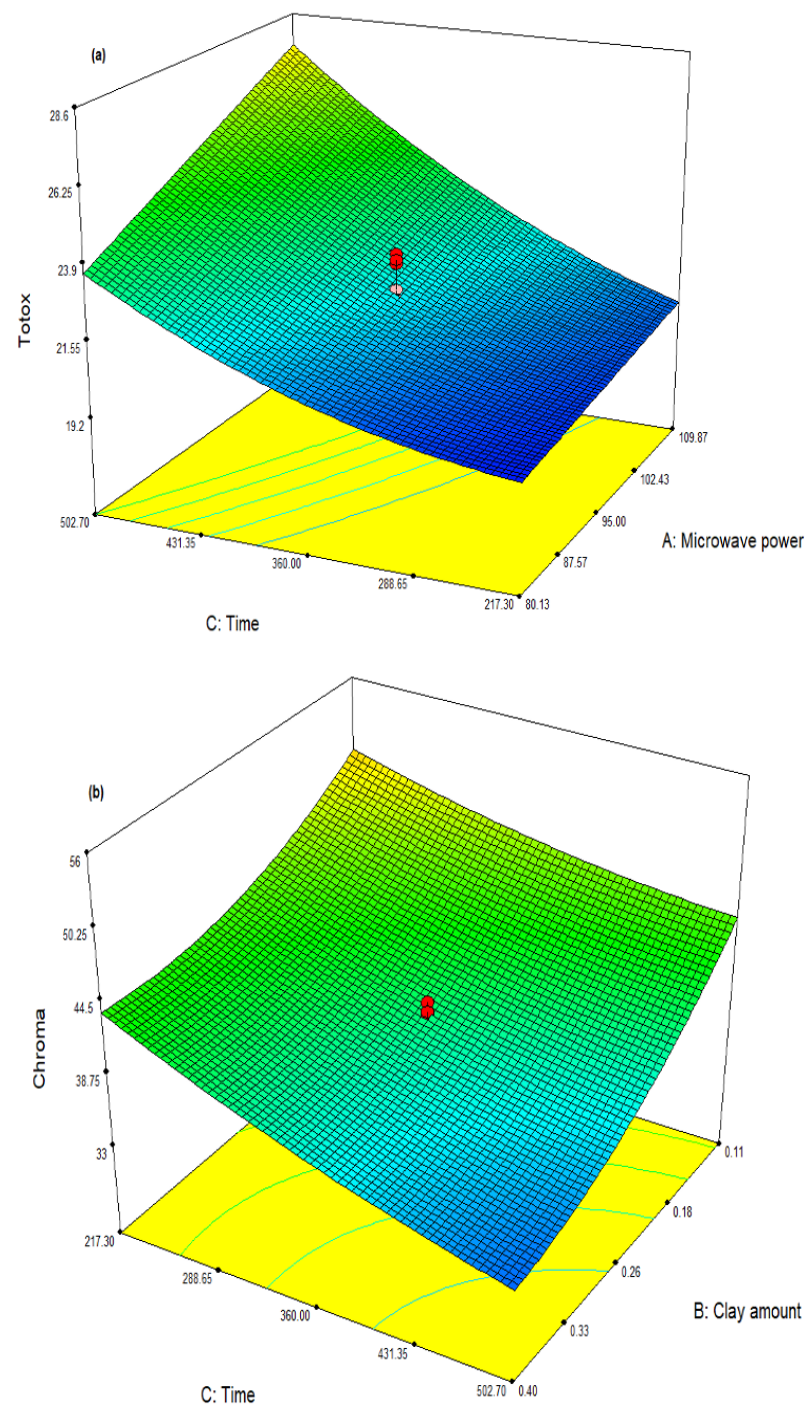

FiguRE 1. 3D response plots of significant interactions between totox value and chroma.

high microwave power negatively affected the oxidation stability of the oil. Marrakchi et al. (2015) stated that the bleaching temperature significantly affects oxidation stability. In another study in which the optimization of industrial bleaching conditions was studied, it was emphasized that temperature and bleaching earth had significant effects on totox values (Chew et al., 2017). Contrary to the findings of Chew et al. (2017) the amount of clay in MWB was not found to be more effective on the totox value than the commercial bleaching process. It may be due to using a small amount of clay and less bleaching time in MWB conditions. İçer and Durak (2018) emphasized that especially p-anisidine and totox value increased as bleaching time increased in both conventional and ultrasonic bleaching methods. The maximum totox value (29.91) obtained from MWB was found to be comparable to the totox value (31.07) re- 
ported by İçyer and Durak (2018) for 30 min conventional bleaching. In general, increasing the amount of clay can facilitate the removal of unwanted compounds in the oil during bleaching. On the other hand, the catalytic properties of acid-activated bleaching earth convert hydroperoxides into secondary oxidation products. Consequently, this situation affects the totox value (Zschau, 2000; Bonveh et al., 2001). It is quite clear from our findings that the low microwave power $(80 \mathrm{~W})$ and short processing time $(8 \mathrm{~min})$ has no effect on oil quality and only a small effect on peroxide and p-anisidine values of the oil processed by microwave. Even if the totox value increased slightly with increasing peroxide and $\mathrm{p}$-anisidine values, they are similar to the findings obtained by the conventional bleaching process (Chew et al., 2017; Zschau, 2000; Bonveh et al., 2001). In addition, it should be kept in mind that the following deodorization process removes the formed oxidation products which are commonly produced in conventional technology, which has been emphasized in the literature in many sources (Shahidi et al., 1997; Zschau, 2001; Skevin et al., 2012).

\subsection{Effect of microwave-assisted bleaching parameters on color properties}

Although the Lovibond tintometer is widely accepted as a standard method for measuring the color of oils, Hunterlab has been used in many studies to measure the color of oils (Abedi et al., 2015; Abedi et al., 2016; Chew et al., 2017). In addition, Abedi et al. (2015) reported a correlation between $\mathrm{b}^{*}$ and $\mathrm{a}^{*}$ values and carotenoid and chlorophyll concentrations, respectively. Hue angle and chroma were monitored for the prediction of color change during the MWB of sunflower oil. While hue angle represents color appearance $\left(0^{\circ}\right.$ : red, $90^{\circ}$ : yellow and $180^{\circ}$ : blue), chroma is defined as a measurement of whiteness and vividness of color (Mínguez-Mosquera et al., 1991). All independent variables (A, B and C) were found to be significantly effective on the hue angle and chroma value. In addition, some interactions such as microwave power/ amount of clay (AB), amount of clay/time (BC) and second-order term of time $\left(\mathrm{C}^{2}\right)$ were found to be significantly effective $(\mathrm{p}<0.05)$ on the hue angle. García-Moreno et al. (2013) found a similar correlation between hue angle and chroma. Response surface plots for chroma and hue angle values for bleached sunflower oil samples as a function of independent variables are shown in Figures $1 b, 2 a$ and $2 b$, respectively. Based on Figure 2a, microwave power and amount of clay had significantly positive effects on hue angle. Moreover, interactions between microwave power and amount of clay had a synergistic effect on hue angle. The interaction of microwave power and amount of clay caused an increase in hue angle. This means that the redness was removed from the sunflower oil. Bleaching time was found as another important parameter for hue angle. In particular, interaction of time and amount of clay
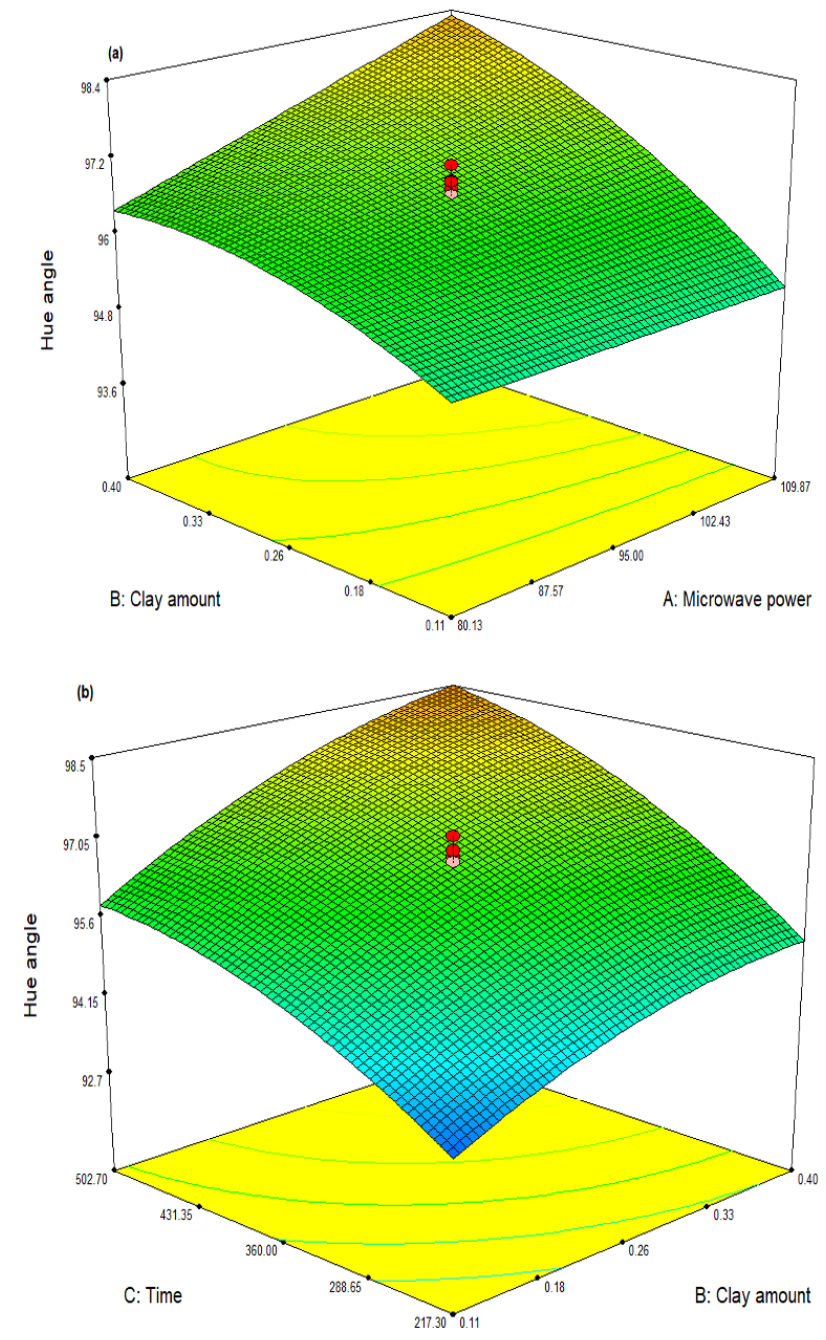

FIGURE 2. 3D response plots of significant interactions for hue angle.

caused a positive effect on the hue angle (Figure 2b). Furthermore, the second order effects of these two variables on the hue angle had a negative coefficient which means that these variables had reached an optimum value in the studied range. In other words, the increase in time and amount of clay did not cause further rising in hue angle after a certain point. Interactions of $\mathrm{BC}$ and second-order term of amount of clay $\left(\mathrm{B}^{2}\right)$ were found significant on the chroma. Chroma value decreased with increasing amount of clay and time and vice versa (Figure $1 \mathrm{~b}$ ). A negative correlation was determined between the hue angle and chroma value. Although the hue angle increased, the chroma values decreased. Marrakchi et al. (2015) reported a similar trend in their study.

\subsection{Optimization and model verification}

The optimization of MWB was carried out by minimizing totox and chroma, maximizing hue angle in sunflow- 
TABLE 3. Comparison of experimental and estimated values for each response under optimum conditions

\begin{tabular}{cccc}
\hline Response & Experimental & Predicted & p value \\
\hline Totox value & $23.31 \pm 0.28$ & 22.48 & 0.13 \\
Hue angle & $96.91 \pm 0.02$ & 97.28 & 0.19 \\
Chroma & $37.66 \pm 0.02$ & 35.67 & 0.08 \\
\hline
\end{tabular}

\pm Standard Deviation. Data are means of triplicates.

er oil samples. Under optimal conditions, the temperature started at ambient temperature and reached $100{ }^{\circ} \mathrm{C}$ at the end of bleaching. In other words, the temperature increased during the treatment period but remained below $100{ }^{\circ} \mathrm{C}$ without applying vacuum. Optimal conditions for MWB were found as $80 \mathrm{~W}, 8.0 \mathrm{~min}$ and $0.4 \%$ for microwave power, time and amount of clay, respectively. Compared to studies in the literature on reducing clay and bleaching time, it was shown that optimized MWB conditions provided more effective decreases. For example, Abedi et al. (2015) reported that two optimized bleached oils were produced by using 1.22 and $1.35 \%$ clay amount in 28 minutes. In a different study on the bleaching of sunflower and soybean oil by using a high voltage electric field, the same researchers (2016) found optimal conditions at $1 \%$ clay amount and 20 minutes; $0.5 \%$ clay amount and 20 minutes for soybean and sunflower oil, respectively. In another study Asgari et al. (2017) studied the bleaching of olive oil and they obtained 13 minutes and $1.21 \%$ for bleaching time and amount of clay. The bleaching time could not be decreased below 10 minutes in any of these studies. It ranged from $15 \mathrm{~min}$ to $30 \mathrm{~min}$. In these studies, the amount of clay used was at its minimum at $0.8 \%$ as determined by İçyer and Durak (2018). Temperature is one of the important parameters for effective bleaching. The temperature values used in the ultrasonic bleaching process can be a limiting factor because with the rapid increase in the liquid temperature, a dense bubble formation begins in the liquid and continues increasingly. But the tendency of the bubbles to collapse becomes harder due to the high pressure inside of them acting as a bed (Thompson and Doraiswamy, 1999). Therefore, in the ultrasound-assisted bleaching process, the bleaching effect at high temperatures needed for obtaining the desired oil quality cannot be due to sonication (Abedi et al., 2015). In addition, in cases where high temperatures are inevitable, unwanted taste and odors have been observed in the ultrasonic method (Jahouach-Rabai et al., 2008). But due to having lower specific heat, vegetable oils can be heated to high bleaching temperatures easily in a short time by microwave, which is an important advantage compared to the ultrasound method. Abedi et al. (2016) used 1.5\% bleaching earth and 30 minutes bleaching time to imitate the industrial process as a control system. The microwave bleaching results showed that MWB was more advantageous in terms of clay usage $(0.4 \%)$ and bleaching time ( 8 min) than those used in industrial processes.
For verification of the response values estimated as a result of the optimization, three independent MWB bleaching studies were carried out under optimal conditions and experimental response values were determined. Experimental and estimated values for each response under optimal conditions are given in Table 3 . The adequate precision values obtained from Design Expert for totox, hue angle and chroma were found to be 23.31, 96.91 and 37.66 , respectively. One-way t-test showed that there was no statistically significant difference between the experimental data and the predicted values for all three responses $(p>0.05)$.

\section{CONCLUSIONS}

Microwave was used for bleaching for the first time in this study. The optimization of MWB conditions (microwave power, time and amount of clay) was successfully achieved by using RSM. Optimum values for MWB were found as $80 \mathrm{~W}, 8 \mathrm{~min}$ and $0.4 \%$ for microwave power, bleaching time and amount of bleaching, respectively. Under optimum conditions the adequate precision values obtained for hue angle, chroma and totox value were found to be $96.91,37.66$ and 23.31. The microwave power, time and amount of clay used were found as significantly effective parameters on the MWB for color parameters. The amount of clay was not significantly effective on the totox value. However, totox value was also significantly affected by microwave power and time. Bleaching time and the amount of clay used for the MWB of sunflower seed oil were found to be the lowest values compared to new bleaching technologies such as ultrasound and high voltage electric field bleaching methods. Therefore, it can be concluded that MWB seems to be a promising technology for the bleaching of oils.

\section{ACKNOWLEDGMENTS}

This research was funded by the Scientific and Technological Research Council of Turkey (TUBITAK) 1002 Project No: 2170348.

\section{REFERENCES}

AOCS. 1998. In Firestone D. (Ed.), Official Methods and Recommended Practices of the American Oil Chemists' Society. AOCS Press, Champaign, USA. 
Abedi E, Sahari MA, Barzegar M, Azizi MH. 2015. Optimisation of soya bean oil bleaching by ultrasonic processing and investigate the physico-chemical properties of bleached soya bean oil. Int. J. Food Sci. Technol. 50, 857-863. https://doi.org/10.1111/ijfs.12689

Abedi E, Sahari MA, Barzegar M, Azizi MH. 2016. Designing of high voltage electric field for soybean and sunflower oil bleaching. Innov. Food Sci. Emerg. 36, 173-180. https://doi.org/10.1016/j.ifset.2016.06.015

Asgari S, Sahari MA, Barzegar M. 2017. Practical modeling and optimization of ultrasound-assisted bleaching of olive oil using hybrid artificial neural network-genetic algorithm technique. Comput. Electron. Agric. 140, 422432. https://doi.org/10.1016/j.compag.2017.06.025.

Bonveh JS, Torrent MS, Coll FV. 2001. A laboratory study of the bleaching process in Stigmasta-3,5-diene concentration in olive oils. J. Am. Oil Chem. Soc. 78, 305-10. https://doi.org/10.1007/s11746-001-0261-8

Boukerroui A, Ouali MS. 2002. Edible oil bleaching with a bentonite activated by micro wave irradiation. $A n$ nales de Chimie 27, 73-81. https://doi.org/10.1016/ S0151-9107(02)80020-4

Boroujeni S, Ghavami M, Piravi Vanak Z, Ghasemi Pirbalouti A. 2020. Optimization of sunflower oil bleaching parameters: using Response Surface Methodology (RSM). Food Sci. Tech-Brazil 40, 322-330. https:// doi.org/10.1590/fst.10919

Chew SC, Tan CP, Nyam KL. 2017. Optimization of bleaching parameters in refining process of kenaf seed oil with a central composite design model. J. Food Sci. 82, 1622-1630. https://doi.org/10.1111/1750-3841.13758

Foletto EL, Paz DS, Gündel A. 2013. Acid-activation assisted by microwave of a Brazilian bentonite and its activity in the bleaching of soybean oil. Appl. Clay Sci. 83, 63-67. https://doi.org/10.1016/j.clay.2013.08.017

Garcia-Moreno PJ, Guadix A, Gómez-Robledo L, Melgosa M, Guadix EM. 2013. Optimization of bleaching conditions for sardine oil. J. Food Eng. 116, 606-612. https://doi.org/10.1111/ijfs. 12527

Gasemloo S, Khosravi M, Sohrabi MR, Dastmalchi S, Gharbani P. 2019. Response surface methodology (RSM) modeling to improve removal of $\mathrm{Cr}$ (VI) ions from tannery wastewater using sulfated carboxymethyl cellulose nanofilter. J. Clean. Prod. 208, 736-742. https://doi.org/10.1016/j.jclepro.2018.10.177

Gjorgjevich MP, Velevska J, Najdoski M. 2012. Effect of microwave radiation on dielectric behavior of two vegetable oils. J. Phys. Sci. 2, 427-433.

Gupta M. 2017. Practical guide to vegetable oil processing. Cambridge.

Hymore FK. 1996. Effects of some additives on the performance of acid activated clays in the bleaching of palm oil. Appl. Clay Sci. 10, 379-385. https://doi. org/10.1016/0169-1317(95)00034-8
İçyer NC, Durak MZ. 2018. Ultrasound-assisted bleaching of canola oil: Improve the bleaching process by central composite design. LWT-Food Sci. Tech. 97, 640-647. https://doi.org/10.1016/j.lwt.2018.07.030

Islam MA, Tan YL, Islam MA, Romić M, Hameed BH. 2018. Chitosan-bleaching earth clay composite as an efficient adsorbent for carbon dioxide adsorption: Process optimization. Colloids and Surfaces A. Colloids Surf. a Physicochem. Eng. Asp. 554, 9-15. https://doi. org/10.1016/j.colsurfa.2018.06.021

Jahouach-Rabai W, Trabelsi M, Van Hoed V, Adams A, Verhé De Kimpe N, Frikha MH. 2008. Influence of bleaching by ultrasound on fatty acids and minor compounds of olive oil. Qualitative and quantitative analysis of volatile compounds (by SPME coupled to GC/ MS). Ultrason Sonochem. 15, 590-597. https://doi. org/10.1016/j.ultsonch.2007.06.007.

Li JW, Zhu LZ, Cai WJ. 2007. Sorption characteristics of surfactant onto bentonite using microwave irradiation. Huan Jing Ke Xue 28, 2642-2645.

Marrakchi F, Kriaa K, Hadrich B, Kechaou N. 2015. Experimental investigation of processing parameters and effects of degumming, neutralization and bleaching on lampante virgin olive oil's quality. Food Bioprod. Process. 94, 124-135. https://doi.org/10.1016/j. fbp.2015.02.002

Meda V, Orsat V, Raghavan V. 2017. Microwave heating and the dielectric properties of foods. Regier M, Knoerzer K, SchubertIn H (Eds), The microwave processing of foods. Woodhead Publishing, 23-43.

Minguez-Mosquera MI, Rejano-Navarro L, Gandul-Rojas B, Sanchez-Gomez AH, Garrido-Fernandez J. 1991. Color-pigment correlation in virgin olive oil. J. Am. Oil Chem. 'Soc. 68, 332-336. https://doi.org/10.1007/ BF02657688

Mustafa AM, Abusabah EK. 2019. Using of Activated Jurdiga for Bleaching of Sunflower Edible Oils. Gezira-J. Eng. Appl. Sci. 13, 2.

Salawudeen TO, Arinkoola AO, Jimoh MO, Akinwande BA. 2014. Clay characterization and optimization of bleaching parameters for palm kernel oil using alkaline activated clays. J. Minerals Materials Character. Eng. 2, 586. https://doi.org/10.4236/jmmce.2014.26060

Schiffmann RF. 2014. Microwave and dielectric drying. Mujumbar A.S (Eds), Handbook of industrial drying. New York: CRC press, 286-306.

Shahidi F, Wanasundara PKJPD, Wanasundara UN. 1997. Changes in edible fats and oils during processing. J. Food Lipids. 4, 199-231. https://doi. org/10.1111/j.1745-4522.1997.tb00093.x

Skevin D, Domijan T, Kraljic K, Gajdos Kljusuric J, Nederal S, Obranovic M. 2012. Optimization of bleaching parameters for soybean oil. Food Technol. Biotechnol. 50, 199-207. 
Su D, Xiao T, Gu D, Cao Y, Jin Y, Zhang W, Wu T. 2013. Ultrasonic bleaching of rapeseed oil: effects of bleaching conditions and underlying mechanisms. J. Food Eng. 117, 8-13. https://doi.org/10.1016/j.jfoodeng.2013.01.039

Thompson LH, Doraiswamy LK. 1999. Sonochemistry: science and engineering. Ind. Eng. Chem. Res. 38, 12151249. https://doi.org/10.1016/j.ultsonch.2015.07.023

Torrealba-Meléndez R, Sosa-Morales ME, Olvera-Cervantes JL, Corona-Chávez A. 2015. Dielectric properties of cereals at frequencies useful for processes with microwave heating. J. Food Sci. Technol. 52, 8403-8409.
Zhang M, Tang J, Mujumdar AS, Wang S. 2006. Trends in microwave-related drying of fruits and vegetables. Trends Food Sci. Technol. 17, 524-534. https://doi. org/10.1016/j.tifs.2006.04.011

Zschau W. 2000. Bleaching. O’Brien, R.D., Farr, W.E., Wan P.J. (Eds), Introduction to fats and oils technology. USA: AOCS Press, 158-178.

Zschau W. 2001. Bleaching of edible fats and oils. Eur. J. Lipid Sci. Technol. 103, 505-551. https://doi. org/10.1002/1438-9312(200108)103:8<505::AIDEJLT505>3.0.CO;2-7 